This item was submitted to Loughborough's Research Repository by the author.

Items in Figshare are protected by copyright, with all rights reserved, unless otherwise indicated.

\title{
Debating health knowledge and health pedagogies in physical education
}

PLEASE CITE THE PUBLISHED VERSION

http://www.routledge.com/9781138580664

PUBLISHER

Routledge

VERSION

AM (Accepted Manuscript)

PUBLISHER STATEMENT

This is an Accepted Manuscript of a book chapter published by Routledge in Debates in Physical Education on 10 December 2019, available online: http://www.routledge.com/9781138580664.

\section{LICENCE}

CC BY-NC-ND 4.0

\section{REPOSITORY RECORD}

Cale, Lorraine, Jo Harris, and Oliver Hooper. 2019. "Debating Health Knowledge and Health Pedagogies in Physical Education”. Loughborough University. https://hdl.handle.net/2134/13259210.v1. 


\title{
DEBATING HEALTH KNOWLEDGE AND HEALTH PEDAGOGIES IN
}

\section{PHYSCIAL EDUCATION}

\author{
Lorraine Cale, Jo Harris and Oliver Hooper
}

\section{Introduction}

The health benefits of physical activity during childhood are now widely recognised and reported. However, if young people are to realise such benefits, they require the necessary knowledge, skills, physical competence and confidence to be able to do so. Physical education is clearly an appropriate context for fostering these attributes in that it provides opportunities to be active and educates about and through physical activity (Harris, 2010). Not surprisingly then, contributing to health and increasing physical activity are viewed by many to be key objectives of the subject (e.g. Fox, Cooper and McKenna, 2004; Fairclough and Stratton, 2005; Trost, 2006). The need to do so is furthermore evident given that the majority of young people do not meet current physical activity guidelines for their health (Harris and Cale, 2018). That said, to date, the seemingly obvious partnership between health and physical education has not been as smooth or straightforward as might be expected and the area has been the topic of much deliberation and critique. This chapter then, focuses on some of the key debates concerning physical education and health. Firstly, it discusses the role and responsibilities of physical education in relation to health, including policy and curricular expectations and healthrelated learning, and some of the challenges to achieving these. Notably, knowledge and teachers' and pupils' health knowledge are considered. The chapter then turns its attention to health pedagogies and to the approaches required or deemed desirable in effectively delivering health within and through physical education. To conclude, a summary of the key debates and some key questions are presented for critical reflection and consideration by the physical education profession moving forwards. 
Role and Responsibilities of PE in Health

The role of physical education in health has long been recognized in many countries. According to Armour and Harris (2013), governments are increasingly looking to schools as a convenient form of public health investment. Recent examples of this in the United Kingdom (UK) include 'Sporting Future': A New Strategy for an Active Nation (HM Government, 2015) and Childhood Obesity: A Plan for Action. (HM Government, 2016). Indeed, physical education's role in health is arguably appropriate for a variety of reasons. For example, physical education is a compulsory or well established component of the curriculum in many countries and therefore provides a captive audience and access to most young people (Cale, 2017). The subject also provides a context for learning at a time of high receptiveness and a workforce with, at least in theory, interest and appropriate knowledge and expertise. This latter point is however debated later in the chapter. As outlined in the following section, physical education also has a responsibility to promote the physical development of pupils and teach about health and health issues (Cale and Harris, 2005).

Further, in support of physical education's role in health is the evidence base concerning the impact it can have on physical activity and other outcomes. Numerous studies, summarised in various reviews, have evaluated the effectiveness of physical education or other school-based physical activity interventions (see for e.g. Cale and Harris, 2006; van Sluijs, McMinn and Griffin, 2007; De Meester et al., 2009; Kriemler, 2011; Dobbins et al., 2013). In short, these reviews have revealed that school-based physical activity interventions which include physical education as a key component can be effective and lead to a number of positive outcomes for young people such as improvements in physical activity, knowledge and attitudes (Cale, 2017). 
Despite the above, and physical education intuitively having a role in health, the nature and extent of this has and continues to be debated (O'Sullivan, 2004; Quennerstedt, 2008; Armour and Harris, 2013). Armour and Harris (2013, p.209) argue that 'much of the international PE community is uncertain about... the proper role for PE in health and... about the level of responsibility the profession should accept for children's (let alone adults') health outcomes. Meanwhile, O'Sullivan (2004) notes how, whilst there seems to be agreement that physical education should promote health enhancing physical activity, there are disagreements over the degree to which it should focus on public health goals.

Indeed, a number of authors express caution (Harris, 2010; Cale, Harris and Chen, 2014) and even some scepticism (e.g. Fardy, Azzollini and Herman, 2004; Armour and Harris, 2013) about what the subject can achieve in terms of health and it is important to be realistic in this regard and to appreciate the limitations. Firstly, physical education accounts for only a small proportion of young people's time, much of which justifiably might involve minimal or only light activity (Fox and Harris, 2003; Stratton, Fairclough and Ridgers, 2008; Cale and Harris, 2013), and some of which is arguably being eroded or placed under threat with competing demands from other subjects. Secondly, and within such time constraints, it must be recognised that physical education has a range of objectives and providing and promoting physical activity represents just one of many (Lounsbery et al., 2011). Additional objectives include the development of physical and social skills, moral values, spirituality, intellectual ability, alongside fitness, recreation, and health (Kirk, 2011).

As mentioned above, whilst physical education as a component of physical activity interventions has been shown to have some positive results, it is noteworthy that, to date, most have been ineffective in influencing physical activity out of school (Cale 2017). This may explain Armour 
and Harris's view (2013) that 'there is little robust historical or contemporary evidence to suggest that physical education in most countries has achieved anything significant in terms of encouraging lifelong engagement in physical activity or improving public health' (p. 202). These authors cite low levels of physical activity amongst adults as evidence of this.

In this debate, it is also important to recognise that some authors are particularly critical of physical education's role in health, expressing concerns over the subject's unquestioned 'allegiance to health' and how it legitimates itself on this basis. Regarding this, Evans, Davies and Rich (2004, p. 386) suggest that 'physical education has no more capacity or responsibility to make children, fit, eat well, and be thin than have math teachers the capacity or responsibility to make pupils multimillionaires'. A further issue raised is the uncritical, simplistic and narrow way in which schools and teachers arguably engage in health issues (Evans, 2007; Evans et al., 2008; Wellard, 2012) and how this is then expressed in physical education (and health) curricula and pedagogies, and in the perspectives of teachers and children in schools (see Burrows and Wright, 2004; Evans, Davies and Rich, 2004; Evans et al., 2008; Evans and Rich, 2011). Health pedagogies are explored later in the chapter.

Linked to the above point, some may interpret the goal of physical education in health to be to 'change' young people's physical activity behaviour through education, seeing this as a desirable and realistic outcome. However, it is contended that this aspiration is overly simplistic and arguably should not be the focus of our efforts. Changing health behaviours is complex with numerous factors within and beyond physical education (and schools) influencing young people's physical activity and health (National Institute for Health and Clinical Excellence, 2007). On this issue, Tinning (2010) contests how it is unrealistic to 
expect individuals to change their lifestyles and behaviours simply because they acquire some new knowledge and to expect that knowing 'that', will translate into 'doing', is naïve (p.181).

All things considered then, it is argued that physical education has a key role and responsibility in health in that it makes a clear and important contribution to young people's physical activity and learning about physical activity. However, and for the reasons outlined, it evidently cannot meet all of young people's physical activity and health needs (Fox, Cooper and McKenna, 2004; McKenzie and Lounsbery, 2009), ensure they meet physical activity recommendations, nor be held responsible for improving the health status of all children and young people (Cale and Harris, 2011), and certainly not that of the nation as a whole.

Nonetheless even those critical of the role of physical education in health accept the relationship between health and physical activity in the context of physical education and concur that physical activity should be integral to the subject (Gard and Wright, 2001). Undoubtedly, physical education needs to do what it can in the time available to effectively promote healthy, active lifestyles. In this respect, it is advocated that its role and responsibility should be to stimulate interest, enjoyment, knowledge, competence and expertise in physical activity and sport for health and well-being (Fox, Cooper and McKenna, 2004) amongst all young people, which in turn should empower them to make informed and independent choices concerning their participation. The provision of high quality teaching, and positive, meaningful and relevant physical education and physical activity experiences are considered central to enabling and facilitating this (Cale and Harris, 2013). More is said on this later.

\section{Physical Education and Health Policy and Curriculum Expectations}


123 Health is a longstanding component of physical education and features explicitly in the 124 physical education curricula in many countries. In England, health has become increasingly

125

126

127 prominent within successive versions of the National Curriculum for Physical Education (NCPE) and in the current National Curriculum ensuring that all pupils 'lead healthy, active lives' and 'are physically active for sustained periods of time' represent two of the main aims of the subject (Department for Education, 2013, p. 1). Interestingly though, and despite these aims, references to health-related learning and to health-related activities in the actual programmes of study are limited. How specifically the NCPE aims are to be achieved, and the programmes of study addressed such that pupils have the requisite knowledge and skills with respect to healthy active lifestyles, is thus open to debate. Given this, meeting these requirements would seem to present a challenge for teachers.

To effectively achieve the above aims, and notably for pupils to lead a healthy, active lifestyle, there is evidently a need to first identify the health knowledge, skills and experiences they require to be able to successfully engage in physical activities for life. It is proposed that this must extend beyond the rather limited requirements implied in the NCPE and focus on developing knowledge and understanding, physical competence, behavioural skills, attitudes and confidence to engage in health-enhancing physical activities, embracing a range of sport, dance and exercise experiences including individualised lifetime activities (Cale and Harris, 2005). In 2000, in recognition of this need, and to support teachers in interpreting and meeting earlier NC requirements, a working group was established to achieve consensus on healthrelated learning within the subject. The group comprised representatives of national physical education, sport and health organisations, a key output from which was the publication of national guidance and health-related outcomes for children aged 5 to 16 years (Harris, 2000). These outcomes included cognitive (knowledge and understanding), affective and behavioural 
components and were presented in four categories or areas of learning: safety issues; exercise effects; health benefits; and activity promotion, organised by NC Key Stage or age group (i.e. 5-7 years (KS1); 7-11 years (KS2); 11-14 years (KS3) and 14-16 years (KS4)), to illustrate the scope of and progression in learning. As Cale and Harris (in press) explain, for individuals to successfully engage in physical activity for life, it is important that they know and understand i) how to take part in physical activity safely and effectively (safety issues); ii) the body's response to participating in physical activity (exercise effects); iii) the reasons for participating in physical activity (health benefits), and iv) what physical activity to take part in, where and how (activity promotion). The outcomes are outlined fully elsewhere (see Harris, 2000; Harris and Cale, 2018) but a few examples for each age range and category are shown in Table 1.

(Insert Table 1 here).

Despite the breadth of health-related learning depicted in the four categories above, research has revealed that, in practice, physical education teachers typically focus on the more instrumental outcomes, for example, those relating to safety issues (i.e. safe practice and warming up and cooling down) and exercise effects (i.e. the short term effects of exercise on the body) rather than on those associated with health benefits and activity promotion (Harris, 2010). Yet, it is evidently the latter outcomes which are more closely linked to lifelong participation in physical activity. Alfrey and Gard (2014) similarly highlight how the profession is renowned for focussing on dualistic and instrumental understandings of health and the body, and how in turn this results in teachers focussing on the same narrow instrumental outcomes in their delivery. The need for more attention to be paid to health and 
activity promoting outcomes is therefore recommended (Harris, 2000; Harris and Cale, 2018). The notion of breadth is discussed further in the next section.

\section{Current Challenges to Meeting Physical Education and Health Policy and Curriculum}

\section{Expectations}

Having debated the role, responsibilities and policy and curriculum expectations regarding physical education and health, this section focusses on some of the challenges the subject faces in achieving these. A number of issues regarding the delivery of health in physical education have been identified in the literature which undoubtedly impact on the effectiveness with which the area is addressed and the extent to which the desired outcomes are met.

A particular challenge relates to concerns about the status afforded to health within physical education. For example, although physical education teachers see health as an important objective of the subject and purport to value it (Cale, Harris and Duncombe, 2016; Alfrey, Cale and Webb, 2012), their practices and approaches do not necessarily reflect this. Studies have revealed that even teachers who cite health as an important aspect of physical education see and tend to use sport as the main vehicle for promoting and achieving this (Green 2009; Alfrey, Cale and Webb 2012). Alongside sport, fitness and fitness related activities have also been reported to dominate teachers' practices (Alfrey, Cale and Webb, 2012; Harris and Leggett, 2015). In their study of health-related policy and practice in secondary schools in England and Wales, Harris and Leggett (2015) found that, whilst many physical education teachers articulated a 'fitness for life' philosophy, their delivery was usually expressed in terms of a 'fitness for performance' discourse, dominated by testing and training. The above suggests that many teachers apply a narrow sport, performance and fitness-oriented approach to the teaching 
of health in physical education (Harris and Leggett, 2015; Alfrey, Cale and Webb, 2012; Puhse et al., 2011) which reflects Green and Thurston's (2002) view that the ideology of sport penetrates deeply into the core assumptions of physical education teachers with regards the promotion of health through the subject.

The approach outlined above is concerning as it restricts provision to other broader educational experiences and to a range of non-competitive, more recreational and individual lifetime activities, which in turn may limit learning (Alfrey, Cale and Webb, 2012; Cale, Harris and Duncombe, 2016). Furthermore, it has arguably led to some unappealing and undesirable practices such as forced fitness regimes, directed activity and dull, dreary drills which equally limit learning, turn many young people off physical activity, and which are counterproductive to the promotion of active lifestyles (Cale and Harris, 2005; 2009). A broader approach has therefore been called for which focuses on development in four domains, the cognitive, psychomotor, behavioural and affective (Harris, 2000), all of which are represented in the health-related outcomes identified earlier, and which adopts a sociallycritical perspective to teaching and learning about health (Quennerstedt, 2008; Burrows, Wright and McCormack, 2009; Haerens et al., 2011). A clear challenge for the profession is thus to combat prevailing sport and fitness ideologies and work towards a more holistic and critical approach, thereby creating a climate of change (Kirk, 2011; Alfrey and Gard, 2014).

Another challenge and one which may explain but also serve as a barrier to achieving the above, relates to physical education teachers' reported limited health knowledge and the implications of this for their practice (Fardy, Azzollini and Herman, 2004; Trost, 2006; McKenzie, 2007; Castelli and Williams, 2007; Kulinna et al., 2008; Keating et al., 2009; Puhse et al., 2011; Alfrey, Cale and Webb, 2012; Cale and Harris, 2013; Harris and Leggett, 
2015; Hastie, 2017). It has been suggested this stems from teachers' often limited training and/or engagement in relevant professional development (Castelli and Williams, 2007; Trost, 2006; McKenzie 2007; Kulinna et al., 2008; Alfrey, Cale and Webb, 2012; Armour and Harris, 2013). Indeed, teachers' limited training, knowledge and pedagogies to deliver the area well have led Armour and Harris (2013) to question whether health aspirations can ever be fully realised within physical education.

Furthermore, and not surprisingly then, concerns have likewise been raised over pupils' health-related knowledge and understanding (Harris et al., 2016a; Hooper, Harris and Cale, 2017a; 2017b). Early research by Harris in the 1990s expressed concerns about what pupils knew and understood about health, fitness and physical activity (Harris 1993; 1994). In particular, it was highlighted that pupils had difficulty in distinguishing between these concepts and held a number of misconceptions related to them, such as exercise having to be hard to be good and being thin equating to being healthy (ibid). Subsequently, research on this topic has emanated from the UK, Australia, New Zealand and the United States, revealing similar findings (Placek et al., 2001; Burrows, Wright and Jungersen-Smith, 2002; Stewart and Mitchell, 2003; Burrows, 2008; Burrows, Wright and McCormack, 2009; Keating et al., 2009; Burrows and Wright, 2010; Roth and Stamatakis, 2010; Brusseau et al., 2011; Powell and Fitzpatrick, 2015; Harris et al, 2016a; Hooper, Harris and Cale, 2017a; 2017b).

Moreover, despite policy, curricular and pedagogical developments in this area, recent work by Hooper, Harris and Cale $(2017 \mathrm{a} ; 2017 \mathrm{~b})$ has identified that still little has changed with regard to pupils' conceptions of health, fitness and physical activity. Findings from this 
research reiterate those of earlier studies, revealing pupils to have predominantly corporeal notions of health, narrow views of what it means to be 'healthy' (focused on diet and exercise as key moderators of health), and a tendency to describe health in negative terms, explicating what not to do to be 'healthy', rather than what to do (ibid). In summarising the body of research in this area, Harris et al., (2016a) concluded that pupils have reductive, limited and limiting conceptions of health.

As research around pupils' knowledge and understandings has advanced, increased attention has been paid to how pupils come to learn about the concepts of health, fitness and physical activity and the sources of information they draw upon. On this, and in accordance with the point made earlier, Burrows and Wright (2010) suggest that pupils' knowledge and understandings of health, fitness and physical activity are reflections of the narrow and somewhat limited teaching taking place within schools, influenced by wider societal messages around public health, which in turn are often influenced by healthist discourses ${ }^{1}$. Meanwhile, Harris et al., (2016a) and Hooper et al., (2017a; 2017b) note how pupils receive health-related information from a range of sources and report difficulty in making sense of this, particularly where it is contrasting or conflicting. Evidently, this highlights the need to consider approaches to the delivery of health which might better facilitate health-related learning within physical education in the broadest sense.

\footnotetext{
${ }^{1}$ Healthism regards health as being attained primarily through the modification of lifestyles. The limitations of this are that it tends to hold individuals responsible for their health and/or health behaviours and assumes they have control and the capacity to make changes/decisions for themselves, failing to acknowledge the influence of other factors in the wider environment.
} 


\section{Health Approaches and Pedagogies in Physical Education}

As already alluded to, if health policy and curricular expectations are to be effectively realised in physical education, then health needs to be afforded appropriate status and prominence and its content, organisation and delivery need to be appropriate, sufficiently broad and explicit. With regards delivery, there are some general principles which should be applied (Cale and Harris, in press). First, physical education is, by definition, concerned with the physical and as such health knowledge and skills should be developed within and through the physical, and via active participation in a range of activities. Evidence suggests however, that this is not always the case, with classroom-based delivery of health and health-related concepts and information often reported (Cale and Harris, 2006; Cale, 2017). This is despite it being found to be relatively ineffective (Cale and Harris, 2006) and limited by its sedentary and didactic nature, thereby reducing the potential both for active time and for learning about health via a combination of understanding, experiencing, decision making and evaluating (Cale and Harris, 2013; Cale, 2017). On the other hand, learning about health through active participation is in keeping with the physical context of the subject, is associated with physical activity for health recommendations and public health messages, and helps to contribute to young people's overall physical activity levels (Harris, 2000; Harris and Cale, 2018).

Other principles which are fundamental to health in physical education, and arguably to high quality teaching in general, are the inclusion and empowerment of all pupils, and their subsequent and gradual shift from dependence on the teacher to independence (Cale and Harris, in press). As noted earlier, providing positive, relevant and meaningful physical activity experiences is key to facilitating and achieving active lifestyles amongst young people. This also needs to involve recognition of the diverse physical activity needs of young people and planning appropriately to meet them. Indeed, three core elements have been 
identified as important to the empowerment of young people with respect to healthy, active lifestyles, namely: appropriate content, appropriate context and effective pedagogy (Elbourn and James, 2013). Appropriate content is safe, progressive, relevant, well informed, inclusive, and fun, whilst appropriate context relates to the range of activities through which healthy, active lifestyles can be promoted, for instance, via a variety of games, dance, gymnastics and exercise activities. Effective health pedagogy meanwhile is characterised by being 'personalised, enabling and collaborative' plus pedagogy which 'facilitates informed decision making' and 'uses active learning strategies' (Elbourn and James, 2013, p.2).

A range of approaches can be used to incorporate health within the curriculum which equally have been the subject of much debate and critique over the years (Cale and Harris, 2005; 2009; 2013; Murdoch and Whitehead, 2010). For example, health can be permeated through core physical education activities such as athletics, dance, games, gymnastics, outdoor education and swimming, or taught in discrete, separate health-related units of work. The strengths of the permeated approach are that health knowledge, understanding and skills can be seen as integral to all physical education experiences, with young people learning that all physical activities can contribute towards health, thus endorsing the close relationship between health issues and participation (Harris, 2000; Murdoch and Whitehead, 2010). However, a major limitation of the approach is that it can be rather 'ad hoc', 'piecemeal' and 'hit and miss' (Harris, 2000, p.168, p.170) and may result in health-related learning becoming 'lost' or marginalised and taking second place to other learning such as skill development or tactical understanding (Cale and Harris 2005; Harris and Cale, 2018). Furthermore, much liaison activity is required to ensure consistent delivery and messages and the approach may deny pupils the opportunity to engage in a variety of popular health-promoting lifetime activities (Fox and Harris, 2003). The discrete approach avoids the above issues, but a drawback in teaching health in isolation is that 
it may not be seen to relate closely to other learning and elements of physical education and other curriculum subjects (Murdoch and Whitehead, 2010; Harris and Cale, 2018). On balance, a combined approach is advocated in that it builds on the strengths of each, helps to reinforce and ensure the consistency and coherence of learning, and provides a realistic opportunity to more adequately address the required knowledge base (Cale and Harris, 2009). It is suggested this approach also places value on the area and allows links to be made to other physical education and physical activity experiences and health behaviours as well as subjects such as personal, social and health education (PSHE), science and food technology (Harris and Cale, 2018). Cale and Harris (2013) contest though that more important than the particular approach adopted, is the effectiveness of its delivery.

Yet, with regards the above, it has been argued that teachers lack appropriate pedagogies for effectively delivering the area (Armour and Harris, 2013). Despite interest in health-focussed curriculum activities and interventions, Armour and Harris (2013) claim less attention has been afforded to the development of pedagogies to be used in the health dimension of physical education (or PE-for-health pedagogies) and which might enable the profession to make a more robust contribution to policy and practice in the area. Indeed, knowledge about effective PE-for-health pedagogies or models has been identified as a significant gap in the field, with calls having been made for alternative methods, strategies or models to teach health-related knowledge (Haerens et al., 2011; Armour and Harris, 2013; Hastie, Chen and Guarino, 2017; Hodges et al., 2017). Armour and Harris (2013) furthermore argue that the traditional approach to the area has been for the curriculum, programmes and activities to drive the educational process but contend that effective PE-for-health pedagogies should place the pedagogical encounter and the needs of the learners at the core. To this end, there 
340 have been some recent and encouraging pedagogical developments in this area within and 341 beyond the UK, a few examples of which are now outlined.

\section{Specific Approaches and Models}

The Health-Based Physical Education (HBPE) Model has as its central theme 'pupils valuing a physically active life, so that they learn to value and practice appropriate physical activities that enhance health and wellbeing for the rest of their lives' (Haerens et al., 2011, p. 321).

The model draws on self-determination theory, the social ecological model and theories of behaviour change and identifies four goals for HBPE including the characteristics of habitual, motivated, informed and critical 'movers'. The affective domain is prominent in planning for learning, emphasising the importance of valuing a physically active life as a sustainable longterm process, knowledge as a significant component, and of focussing beyond the individual to the wider community. In this respect, and whilst intended to be used flexibly to inform learning outcomes and the delivery of health knowledge and content, the model proposes that:

- Pupils' psychological needs for autonomy, competence and relatedness should be prioritised;

- Teachers promote physical activity within and beyond lessons, maximising lesson opportunities and interacting with parents and community bodies;

- Lessons include physical activity learning opportunities, such as current guidelines, age-related statistics, local opportunities and safe/effective practice;

- Pupils understand physical activity barriers, potential strategies to overcome these and become movement activists for their peers/family (Bowler et al., 2012). 
363 Since 2011, this model has undergone a comprehensive process of development with 364 teachers, teacher educators and pupils resulting in some positive outcomes for those involved 365 (Bowler et al., 2012; 2015).

367 A second pedagogical approach to promoting knowledge and understanding of health, the Promoting Active Lifestyle (PAL) Principles (Harris, Cale and Hooper, 2017; Harris and Cale, 2018) emanated from a small-scale action research study. The aim was to develop and trial a principle-based approach to promoting active lifestyles which could inform policies, delivery and resources suitable for use by teachers and schools. Informed by the literature and underpinned by social cognitive theory and the social ecological model, experienced and trainee teachers were involved in developing, trialling, evaluating and agreeing a number of whole school and physical education-specific PAL Principles, some of which explicitly focus on the development of knowledge and understanding in this area. Key considerations in the design and implementation of the principles were ensuring their flexibility, simplicity, accessibility and sustainability. Thus, there are no rigid rules and no prescriptive or structured programme for teachers to follow in incorporating them and minimal training and limited resources are needed to do so. The findings from the study were encouraging revealing changes in teachers' pedagogies, increased activity levels and positive responses from pupils (Cale, Harris and Hooper, 2017; Harris, Cale and Hooper 2017).

Examples of whole school PAL Principles which require and involve the development of appropriate knowledge and understanding are: PSHE (alongside other health guidelines) as well as in physical education; 
- Discuss the promotion of active lifestyles, including marketing the 'one hour a day' physical activity guideline, with all staff, governors, pupils and parents/carers;

- Promote active travel to school (cycling, walking, scooting) and ensure safe storage of cycles/scooters;

- Review the school's extra-curricular physical activity programme and consider how accessible/appealing it is for all pupils;

- Develop good community links (e.g. with feeder/partner schools, local leisure centres and sports clubs) to increase the quality and quantity of physical opportunities for pupils.

Likewise, relevant examples of physical education PAL Principles are:

- Teach pupils about the broad range of benefits (physical, psychological and social) of a healthy, active lifestyle, including the role of physical activity in healthy weight management;

- Include assessment of learning and progress in active ways (e.g. show me....; demonstrate....; shadow....);

- Routinely inform pupils where they can be active within 3-5 miles of the school radius (in every unit of work and via the school's intranet/library);

- Teach pupils how active they should be, involve them in monitoring their activity levels so they become aware of how active they are, and inform them of multiple ways of increasing their activity levels;

- Identify low active pupils and offer them (and their parents/carers) support/guidance/information and targeted/bespoke activity sessions Taken from Harris et al., (2016b, p. 52) 
411 The Project-Based Learning PBL Model (Hastie, Chen and Guarino 2017) represents another approach to teaching health-related knowledge. Hastie and colleagues (2017) implemented the model during an 18 lesson unit. The 'project' required students to plan a series of exercise stations and create three fitness trails (aerobic, muscular strength/endurance and core strength and flexibility) with the teacher providing in-class fitness education and facilitating the design of the trails. Seven essential elements of meaningful projects identified by Larmer and Mergendoller (2010, cited in Hastie et al., (2017)) were adhered to, these being: a need to know; a driving question; student voice and choice; $21^{\text {st }}$ century skills; inquiry and innovation; feedback and revision; and a publicly presented project. The unit was found to be effective in enhancing students' fitness knowledge and PBL was therefore advocated as an alternative approach to teaching meaningful fitness education, particularly for primary school children (Hastie, Chen and Guarino, 2017).

Each of the above approaches is innovative and different in its own right and studies on each have, to date, resulted in positive outcomes for teachers and pupils. This is promising and illustrates the potential of such approaches and pedagogies to impact on young people's health knowledge and physical activity behaviours. Teachers should therefore be encouraged to experiment with similar as well as further pedagogical approaches in order to enhance their delivery of health and ultimately effectiveness in promoting healthy, active lifestyles.

Finally, and mindful of the pace of technological advances in contemporary society, it would be remiss not to consider the influence of technology in the development of health knowledge and pedagogies. In recent years there has been a rapid growth in both the availability and application of digital technologies within physical education (Casey, Goodyear and Armour, 
2017) and, increasingly, these digital technologies are being used for the purposes of healthrelated teaching and learning within the subject (Gard, 2014). Examples include exergames (Öhman et al., 2014; Francombe-Webb, 2016), apps and wearables (Goodyear, Kerner and Quennerstedt 2017; Rich and Miah, 2017). The integration of these technologies is typically justified by the potential they are assumed to have to promote health, with studies suggesting that they can increase physical activity levels, enhance perceptions of body image and improve dietary behaviours (Dennison et al., 2013; Dute, Bemelmans and Breda, 2016).

However, despite the potential benefits digital technologies may offer in this regard, concerns have been expressed over the potentially negative impact they might have on teaching practice, pupil learning and pupil wellbeing. Indeed, preliminary findings from the PAL project suggest that whilst physical education teachers are interested in the use of technology to enhance both the emphasis on, and interest in, health-related knowledge and behaviour amongst their pupils, they are equally mindful that technology can be limiting and can reduce physical activity levels. This represents somewhat of a dilemma. Currently for many of these teachers their search for pedagogically appropriate technology to enhance teaching and learning is also proving time-consuming and frustrating.

A particular concern with such technologies is their tendency to 'quantify' health-related learning, for example, by measuring and ranking pupils in terms of physical activity levels. As Goodyear, Kerner and Quennerstedt (2017, p. 2) note, this could lead to health-related learning 'becoming a practice of being told, adopting and repeating easily described behaviours', such as exercising for 60 minutes per day at moderate to vigorous intensity. This is problematic given the limitations concerning pupils' knowledge and understandings and the concerns over unappealing and undesirable health-related teaching practices highlighted 
earlier. In addition, and again linked to a limitation in delivery acknowledged earlier, it may further reinforce a narrow, fitness focus within physical education. As such, it is proposed that rather than teachers using digital technologies to develop and introduce new, innovative approaches to teaching about health, many might just be using new tools for old tricks. A final concern expressed over digital technologies is that they promote surveillance practices, including self-tracking (Williamson, 2015; Rich and Miah, 2017). Such practices it is suggested can negatively impact on young people's health and wellbeing by encouraging obsessive/addictive monitoring behaviours (Lupton, 2016) and increasing bodily comparison and potentially dissatisfaction (Lewallen and Behm-Morawitz, 2016).

Despite the above, Kirk (2011) has argued that schools and physical education need to adapt to integrate digital technologies within their practice and given their widespread prevalence and use amongst young people, this would seem to be the case. Perhaps more importantly however, in order for practice to be progressive, Casey, Goodyear and Armour (2016) claim that the focus needs to shift from digital technologies (i.e. the tools) to digital pedagogies. They explain:

Pedagogies of technology are critically aware and technically competent pedagogies that can be developed in practice to maximise the latent potential of technologies to accelerate learning in meaningful ways that meet the individual needs of diverse learners. The starting point for a pedagogy of technology is a desire to do things differently, rather than do the same things using 'flashy' tools and gizmos (p. 6)

Evidently, if digital technologies are to be used for teaching and learning about health within physical education, which appears to be inevitable, consideration needs to be given to their pedagogical application to ensure that they facilitate appropriate content, appropriate context 
and effective pedagogy (Elbourn and James, 2013). Clearly more work is needed to identify and develop effective technological tools and pedagogies of technology which can be employed in the context of health-related learning in physical education.

\section{Summary}

This chapter has focussed on some of the key debates concerning physical education and health. It began by exploring the role and responsibilities of physical education in relation to health, surmising that the subject does have a key role to play and makes an important contribution to young people's learning about and engagement in physical activity. However, at the same time, it cautioned that there are limitations in terms of what it can realistically achieve. The chapter then outlined the policy and curricular expectations with respect to health and health-related learning within physical education. With reference to the NCPE in England and to support teachers in meeting the health-related aims of the curriculum, health-related pupil outcomes covering cognitive, affective and behavioural components were shared.

Various challenges to achieving these, and which impact on the effectiveness with which the area is addressed more broadly were then highlighted, including the status of health within physical education and limitations in teachers' delivery, practice, and knowledge and understanding with respect to health. Further, it was acknowledged how these in turn can lead to limitations in pupils' knowledge and understanding. The following section then considered some of the key principles, approaches and PE-for-health pedagogies required or deemed desirable in effectively delivering health within and through physical education. Knowledge about the latter was identified as a key gap in the field, but some recent promising, innovative pedagogical developments were highlighted including the Health-Based Physical Education (HBPE) Model, the Promoting Active Lifestyle (PAL) Principles, and the Project-Based Learning (PBL) Model. Finally, the influence, as well as the potential limitations of digital 
510

511

512

513

514

515

516

517

518

519

520

521

522

523

524

525

526

527

528

529

530

531

technologies in the development of health knowledge and pedagogies were explored and it was acknowledged how more work is needed in identifying and developing effective technological tools and pedagogies in this area. To conclude, some key questions are now presented for critical reflection and consideration moving forwards.

\section{Questions for Reflection}

Do any of these debates and challenges resonate with your experiences of health in physical education? If so, which ones?

How can teachers overcome challenges associated with the status and expression of health in physical education?

How can physical education teachers be supported in further developing their health knowledge and practice?

What would help teachers to explore different, innovative approaches to the promotion of healthy, active lifestyles in physical education?

\section{Further Reading/Resources}

Cale, L. (2017). Teaching about Healthy Active Lifestyles. In C.D. Ennis (Ed.), Routledge Handbook of Physical Education Pedagogies (pp. 399-411). Oxon: Routledge.

This chapter focuses on teaching about active lifestyles as an explicit objective of physical education and addresses a number of areas and issues of relevance to teachers. It explores the context and opportunities physical education affords in this regard, evidence on its effectiveness in influencing young people's physical activity, and some of the 
532 issues faced in teaching about active lifestyles. This includes critiquing some current

533 pedagogy and common practices such as fitness testing.

534

535 Harris, J. and Cale, L. (2018). Promoting Active Lifestyles in Schools, Leeds: Human

536 Kinetics.

537 This book is designed primarily to support schools and teachers in promoting healthy, active

538 lifestyles in a planned, progressive and accessible manner. It addresses curriculum

539 requirements, whole-school and cross-curricular recommendations and expectations,

540 extracurricular opportunities, and links with parents, carers and the community. The book

541 includes research-informed, evidence-based practices and practical ideas, tried and tested

542 learning activities for pupils of various ages, best-practice case studies and a web resource.

543

544 Leahy, D., Burrows, L., McCuaig, L., Wright, J. and Penney, D. (2016) School Health

545 Education in Changing Times, Routledge.

546 This book provides a socio-critical analysis of the key elements of school health education

547 more broadly. It explores health discourses, principles and practices and provides critical

548 insights into the principles and practices underpinning approaches to health education policy,

549 curriculum, pedagogy and assessment in schools. The book draws on extensive literature and

550 research and as such should be of interest to postgraduate students, researchers, academics,

551 teacher educators and teachers. 
556 Alfrey, L. and Gard, M. (2014) A crack where the light gets in: a study of health and physical

557 education teachers' perspectives on fitness testing as a context for learning about health,

558 Asia-Pacific Journal of Health, Sport and Physical Education, 5, 1: 3-18.

559

560 Alfrey, L., Cale, L. and Webb, L. (2012) Physical education teachers' continuing professional 561 development in health-related exercise, Physical Education and Sport Pedagogy, 17, 5: 477562491.

563

564 Armour K.M. and Harris J (2013) Making the case for developing new PE-for-health 565 pedagogies, Quest, 65, 2: 201-219.

566

567 Bowler, M., Sammon, P., Casey, A., Haerens, L. and Kirk, D. (2012) Validating the Health568 Based Physical Education pedagogical model: Defining teacher and student benchmarks, 569 Paper presented at the British Educational Research Association Annual Conference, 570 University of Manchester, 4-6 September.

571

572 Bowler, M., Sammon, P., Kirk, D., Haerens, L., Cale, L. and Casey, A. (2015). Developing a 573 'prototype' Health-Based Physical Education pedagogical model, Paper presented at the 574 International Association for Physical Education in Higher Education (AIESEP) Annual 575 Conference, Universidad Europea, Madrid, Spain.

576

577 Brusseau, T., Hodges Kulinna, P. and Cothran, D. (2011) Health and physical activity content 578 knowledge of Pima children, The Physical Educator, 68, 2: 66-77. 
580 Burrows, L. (2008) "Fit, fast, and skinny": New Zealand school students 'talk' about health,

583 Burrows, L. and Wright, J. (2010). The good life: New Zealand children's perspectives on 584 health and self, Sport, Education and Society, 9, 2: 193-205.

585

Burrows, L., Wright, J. and Jungersen-Smith, J. (2002) "Measure your belly": New Zealand

children's constructions of health and fitness, Journal of Teaching in Physical Education, 22,

588 1: 39-48.

589

590

Burrows, L., Wright, J. and McCormack, J. (2009) Dosing up on food and physical activity:

New Zealand children's ideas about ‘health', Health Education Journal, 68, 3: 157-169.

592

593

Cale, L. (2017) Teaching about Healthy Active Lifestyles. In C.D. Ennis (Ed.), Routledge

Handbook of Physical Education Pedagogies, Oxon: Routledge, 399-411.

595

596

Cale, L. and Harris, J. (2005) (Eds.) Exercise and Young People. Issues, Implications and

Initiatives, Basingstoke: Palgrave Macmillan.

598

Cale, L. and Harris, J. (2006) School based physical activity interventions - effectiveness, trends, issues, implications and recommendations for practice, Sport, Education and Society, 11, 4: 401-420.

602

Cale, L. and Harris, J. (2009) Getting the Buggers Fit (second edition), London: Continuum. 
Cale, L. and Harris, J. (2011) Learning about health through physical education and youth

sport. In K. Armour (ed) Sport Pedagogy An Introduction for Teaching and Coaching,

Prentice Hall, 53-64.

608

Cale, L. and Harris, J. (2013) Physical education and health: considerations and issues. In S.

Capel and M. Whitehead (eds) Debates in Physical Education, Oxon: Routledge, 74-88.

611

612 Cale, L. and Harris, J. (in press) The Role of Knowledge and Understanding in Fostering Physical Literacy, Journal of Teaching in Physical Education.

Cale, L., Harris, J. \& Chen, M.H. (2014) Monitoring health, activity and fitness in physical 397.

Cale, L., Harris, J. and Duncombe, R. (2016) Promoting physical activity in secondary schools. Growing expectations: same old issues, European Physical Education Review, 22, 4: $526-544$.

622

Cale, L., Harris. J. and Hooper, O. (2017) The Promoting Active Lifestyles project. The $30^{\text {th }}$ Conference, University of Canberra, Australia.

627 Casey, A., Goodyear, V. and Armour, K. (2016) Digital Technologies and Learning in 628 Physical Education: Pedagogical Cases, London: Routledge. 
630 Casey, A., Goodyear, V. A. and Armour, K. M. (2017) Rethinking the relationship between 631 pedagogy, technology and learning in health and physical education, Sport, Education and 632 Society, 22, 2: 288-304.

633

634 De Meester, F., van Lenthe, J.J, Spittaels, H., Lien, N. and De Bourdeauhuij, I. (2009) 635 Interventions for promoting physical activity among European teenagers: a systematic 636 review, International Journal of Behavioural Nutrition and Physical Activity, 6, 82: 1-11.

637

638

Department for Education. (2013) Programmes of Study for Physical Education, https://www.gov.uk/government/publications/national-curriculum-in-england-physicaleducation-programmes-of-study

Dennison, L., Morrison, L., Conway, G. and Yardley, L. (2013). Opportunities and challenges for smartphone applications in supporting health behaviour change: Qualitative study, Journal of Medical Internet Research, 15, 4: e86

645

Dobbins, M., Husson, H., DeCorby, K. and La Rocca, R.L. (2013) School-based physical activity programs for promoting physical activity and fitness in children and adolescents aged 6 to 18, Cochrane Database of Systematic Reviews, Issue 2. learned, JMIR mHealth and uHealth, 4, 2: e39. doi: 10.2196/mhealth.3559 
654 Elbourn, J. and James, A. (2013) Fitness Room Activities for Secondary Schools. A Guide to 655 Promoting Effective Learning about Healthy Active Lifestyles, Leeds: Coachwise.

656

657 Evans, J. (2007) Health education or weight management in schools?, Cardiometabolic 658 Risk and Weight Management, 2, 2: 12-16.

659

660

661 Evans, J. and Rich, E. (2011) Body policies and body pedagogies: every child matters in

662 totally pedagogised schools?, Journal of Education Policy, 26, 2: 311-329.

663

664

665 Evans, J., Davies, B. and Rich, E. (2004) The emperor's new clothes: fat, thin, and

666 overweight. The social fabrication of risk and ill health, Journal of Teaching in Physical 667 Education, 23: 372-391.

668

669

Evans, J., Rich, E., Davies, B. and Allwood, R. (2008) Education, Disordered Eating and

670 Obesity Discourse. Fat Fabrications, Routledge: Oxon.

671

672 Fairclough, S. and Stratton, G. (2005) Physical Education makes you Fit and Healthy':

673 Physical Education's Contribution to Young People's Physical Activity Levels, Health

674 Education Research, 20, 1: 14-23. 
676 Gard, M. (2014) eHPE: A history of the future, Sport, Education and Society, 19, 6: 827-845.

677

678 Gard, M. and Wright, J. (2001) Managing uncertainty: obesity discourses and physical 679 education in a risk society, Studies in Philosophy and Education, 20: 235-549.

680

681 Fardy, P.S., Azzollini, A., \& Herman, A. (2004) Health-based physical education in urban 682 high schools: The PATH program. Journal of Teaching in Physical Education, 23: 359-371.

683

684 Fox, K. and Harris, J. (2003) Promoting physical activity through schools, in: J.

685 McKenna, and C. Riddoch (Eds), Perspectives on Health and Exercise, Basingstoke:

686 Palgrave Macmillan, 181-201.

687

688 Fox, K., Cooper, A. and McKenna, J. (2004) The school and promotion of children's 689 health-enhancing physical activity: perspectives from the United Kingdom, Journal of 690 Teaching Physical Education, 23: 338-358.

691

692 Francombe-Webb, J. (2016) Critically encountering exer-games and young femininity, 693 Television and New Media, 17, 5: 449 -464.

694

695 Goodyear, V., Kerner, C. and Quennerstedt, M. (2017) Young people's uses of wearable 696 healthy lifestyle technologies; surveillance, self-surveillance and resistance, Sport, Education

697 and Society, DOI: 10.1080/13573322.2017.1375907. 
699 Green, K. (2009) Exploring the everyday 'philosophies' of physical education teachers from

700

701

702

703

704

705

706

707

708

709

710

711

712

713

714

715

716

717

718

719

720

Green, K. and Thurston, M. (2002) Physical Education and Health Promotion: A Qualitative Study of Teachers' Perceptions, Health Education, 102, 3: 113-123.

Haerens, L., Kirk, D., Cardon, G. and De Bourdeaudhuij, I. (2011) Toward the Development of a Pedagogical Model for Health-Based Physical Education, Quest, 63: 321-338.

Harris, J. (1993) Young people's perceptions of health, fitness and exercise, British Journal of Physical Education Research Supplement, 13: 5 -9.

Harris, J. (1994) Young people's perceptions of health, fitness and exercise: Implications for the teaching of health-related exercise, Physical Education Review, 1, 2: 143-151.

Harris, J. (2000) Health-Related Exercise in the National Curriculum, Leeds: Human Kinetics.

Harris, J. (2010) Health-related physical education. In: R. Bailey (Ed.), Physical Education for Learning: A Guide for Secondary Schools (pp. 26-36), London: Continuum. 
721 Harris, J. and Cale, L. (2018). Promoting Active Lifestyles in Schools, Leeds: Human

722 Kinetics.

723

724 Harris, J. and Leggett, G. (2015) Influences on the expression of health within physical

725 education curricula in secondary schools in England and Wales, Sport Education and Society, $726 \quad 20,7: 908-923$.

727

728

Harris, J., Cale, L. and Hooper, O. (2017) Promoting active lifestyles in schools: From

729 philosophical principles to inclusive pedagogies, The International Association for Physical Education in Higher Education (AIESEP) Conference, University of the Antilles, Guadeloupe.

732

733

Harris, J., Cale, L., Duncombe, R. and Musson, H. (2016a) Young people's knowledge and 734 understanding of health, fitness and physical activity: issues, divides and dilemmas, Sport, Education and Society, DOI: 10.1080/13573322.2016.1228047.

736

737

Harris, J. Cale, L., Casey, A., Tyne, A. and Samaria, B. (2016b) Promoting active lifestyles in 738 schools. The PAL Project, Physical Education Matters, 11, 3: 52-53.

739

740 Hastie, P. A., Chen, S. and Guarino, A. J. (2017) Health-related fitness knowledge

741 development through project-based learning, Journal of Teaching in Physical Education, 36:

742 119-125. 
744 Hodges, M. G., Kulinna, P. H., van der Mars, H. and Lee, C. (2016) Knowledge in action;

745 fitness lesson segments that teach health-related fitness in elementary physical education,

746 Journal of Teaching in Physical Education, 35: 16-26.

747

748 Hooper, O., Harris, J. and Cale, L. (2017a) Speaking up about 'health': Exploring secondary

749 school pupils' understandings and conceptions of healthy, active lifestyles, Australian

750 Council for Health, Physical Education and Recreation (ACHPER) Conference, University

751 of Canberra, Australia.

752

753 Hooper, O., Harris, J. and Cale, L. (2017b) Talking it through: Using youth voice to explore

754 pupils' knowledge, understandings and conceptions of healthy, active lifestyles, European

755 Educational Research Association (EERA) Conference, University College Copenhagen,

756 Denmark.

757

758

HM Government. (2015) Sporting Future. A New Strategy for an Active Nation, London:

759

Author. https://www.gov.uk/government/publications/sporting-future-a-new-strategy-for-an-

760

$\underline{\text { active-nation }}$

761

762

HM Government. (2016) Childhood Obesity. A Plan for Action, London: Author

763

https://www.gov.uk/government/publications/childhood-obesity-a-plan-for-action

764

765 Keating, X.D., Harrison, L., Chen, L., Xiang, P., Lambdin, D., Dauenhauer, B., Rotich, W. and Castro Pinero, J. (2009) An analysis of research on student health-related fitness 
767

768

769

770

771

772

773

774

775

776

777

778

779

780

781

782

783

784

785

786

787

788

knowledge in K-16 physical education programs, Journal of Teaching in Physical Education, 28, 333-349.

Kirk, D. (2011) Physical Education Futures, London: Oxon, Routledge.

Kriemler, S., Meyer, U., Marin, E., van Sluijs, E.M.F., Andersen, L.B. and Marin, B.W. (2011) Effect of school-based interventions on physical activity and fitness in children and adolescents: a review of reviews and systematic update, British Journal of Sports Medicine, 45: 923-930.

Kulinna, P.H., McCaughtry, N., Martin, J.J., Cothran, D. and Faust, R. (2008) The influence of professional development on teachers' psychosocial perceptions of teaching a health-related physical education curriculum, Journal of Teaching in Physical Education, 27: 292-307.

Larmer, J. and Mergendoller, J. R. (2010) Seven essentials for project-based learning, Educational Leadership, 68, 1: 34-37.

Leahy, D., Burrows, L., McCuaig, L., Wright, J. and Penney, D. (2016) School Health Education in Changing Times, Routledge.

Lewallen, J. and Behm-Morawitz, E. (2016) Pinterest or Thinterest?: Social comparison and body image on social media, Social Media \& Society, January-March: 1-9. 
790 Lounsbery, M.A.F., McKenzie, T.L., Trost, S. and Smith, N.J. (2011) Facilitators and 791 barriers to adopting evidence-based physical education in elementary schools, Journal of 792 Physical Activity and Health, 8, 1: S17-S25.

793

Lundvall, S. (2015) Physical literacy in the field of physical education - A challenge and a 795 possibility, Journal of Sport and Health Sciences, 4: 113-118.

796

797

798

Lupton, D. (2016) The diverse domains of quantified selves: Self-tracking modes and dataveillance, Economy and Society, 45, 1: 101-122.

799

800

McKenzie, T.L. (2007) The preparation of physical educators: A public health perspective, 801 Quest, 59: 346-357.

802

803

McKenzie, T.L. and Lounsbery, M.A.F. (2009) School physical education: the pill not 804 taken, American Journal of Lifestyle Medicine, 3, 3: 219-225.

805

806

Murdoch, E. and Whitehead, M. (2010). Physical literacy, fostering the attributes and 807 curriculum planning. In: M. Whitehead (Ed.), Physical Literacy Throughout the Lifecourse, 808 London: Routledge, 175-188.

810 National Institute for Health and Clinical Excellence (NICE) (2007) Physical Activity and 811 Children. Review 1: Descriptive Epidemiology, NICE Public Health Collaborating Centre: $\underline{w w w . n i c e . o r g . u k}$ 
814 Öhman, M., Almqvist, J., Meckbach, J. and Quennerstedt, M. (2014) Competing for ideal

815 bodies: A study of exergames used as teaching aids in schools, Critical Public Health, 24, 2:

$816 \quad 196-209$.

817

818 O’Sullivan, M. (2004) Possibilities and pitfalls of a public health agenda for physical 819 education, Journal of Teaching in Physical Education, 23: 392-404.

820

821

Placek. J., Griffin, L., Dodds, P., Raymond, C., Tremino, F. and James, A. (2001) Middle

822

schools students' conceptions of fitness: the long road to a healthy lifestyle, Journal of

823

Teaching in Physical Education, 20: 314-323.

824

825

Powell, D. and Fitzpatrick, K. (2015) 'Getting fit basically just means, like, nonfat': children's

826 lessons in fitness and fatness, Sport, Education and Society, 20, 4: 463-484.

827

828

Puhse, U., Barker, D., Brettschneider, W.D. et al., (2011) International approaches to health-

829 oriented physical education: local health debates and differing conceptions of health, International Journal of Physical Education, 3: 2-15.

831

832

Quennerstedt, M. (2008) Exploring the relation between physical activity and health - a

833 salutogenic approach to physical education, Sport, Education and Society, 13, 3: 276-283. 
835 Rich, E. and Miah, A. (2017). Mobile, wearable and ingestible health technologies: Towards

836 a critical research agenda, Health Sociology Review, 26, 1: 84-97.

837

838 Roth, M. and Stamatakis, E. (2010) Linking young people's knowledge of public health 839 guidelines to physical activity levels in England, Pediatric Exercise Science, 22: 467-476.

841 Stewart, S. and Mitchell, M. (2003) Instructional variables and student knowledge and 842 conceptions of fitness, Journal of Teaching in Physical Education, 22: 533-551.

Stratton, G., Fairclough, S.J. and Ridgers, N. (2008) Physical activity levels during the school day, in: A. L. Smith and S. J. H. Biddle (Eds), Youth Physical Activity and Sedentary Behaviour. Challenges and solutions, Champaign, IL: Human Kinetics, 321-350.

Trost, S. (2006) Public health and physical education, in: D. Kirk, M. O’Sullivan and D. Macdonald (Eds), Handbook of Physical Education, London: Sage, 163-187.

850

851

van Sluijs, E.M.F, McMinn, A.M. and Griffin, S.J. (2007) Effectiveness of interventions to promote physical activity in children and adolescents: systematic review of controlled trials, British Medical Journal, 335: 703.

Wellard, I. (2012) Body-reflexive pleasures: exploring bodily experiences within the context of sport and physical activity, Sport, Education and Society, 17, 1: 21-33. 
858 Williamson, B. (2015) Algorithmic skin: Health-tracking technologies, personal analytics and 859 the biopedagogies of digitized health and physical education, Sport, Education and Society, $860 \quad 20,1: 133-151$. 
Table 1. Example Health-related Learning Outcomes

\begin{tabular}{|c|c|c|c|c|}
\hline $\begin{array}{l}\text { Learning } \\
\text { Outcome }\end{array}$ & 5-7 Year Olds & 7-11 Year Olds & 11-14 Year Olds & 14-16 Year Olds \\
\hline Safety & $\begin{array}{l}\text { - Identify and adhere to } \\
\text { safety rules and practices } \\
\text { (e.g., changing clothes for } \\
\text { PE; tying long hair back; } \\
\text { not wearing jewellery; } \\
\text { sitting and standing with } \\
\text { good posture; wearing } \\
\text { footwear when skipping } \\
\text { with a rope). } \\
\text { - Explain that activity starts } \\
\text { with a gentle warm up } \\
\text { and finishes with a } \\
\text { calming cool down. }\end{array}$ & $\begin{array}{l}\text { Explain the need for safety } \\
\text { rules and practices (e.g. } \\
\text { adopting good posture, } \\
\text { changing clothes and having } \\
\text { a wash after energetic } \\
\text { activity, wearing suitable } \\
\text { footwear, following rules, } \\
\text { safe lifting). } \\
\text { Identify the purpose of } \\
\text { warming up and of cooling } \\
\text { down and recognise and } \\
\text { describe the parts of a warm- } \\
\text { up and a cool-down: } \\
\text { exercises for the joints (e.g. } \\
\text { arm circles), whole-body } \\
\text { activities (e.g., jogging) and } \\
\text { stretches for the whole (e.g. } \\
\text { reaching long and tall) or } \\
\text { parts of the body (e.g. lower- } \\
\text { leg or calf). }\end{array}$ & $\begin{array}{l}\text { Demonstrate their understanding of } \\
\text { safe exercise practices (e.g., tying long } \\
\text { hair back, removing jewellery, } \\
\text { adopting good posture, performing } \\
\text { exercises with good technique; having } \\
\text { a wash or shower after energetic } \\
\text { activity, administering basic first aid, } \\
\text { wearing adequate protection, coping } \\
\text { with specific weather conditions to } \\
\text { avoid sunburn and prevent dehydration; } \\
\text { following procedures for specific } \\
\text { activities). } \\
\text { Explain the value of preparing for and } \\
\text { recovering from activity and the } \\
\text { possible consequences of not doing so } \\
\text { and more specifically, explain the } \\
\text { purpose of, and plan and perform, each } \\
\text { component of a warm-up and of a cool- } \\
\text { down (i.e. mobility exercises, whole- } \\
\text { body activities, static stretches) both } \\
\text { for activity in general and for specific } \\
\text { activities. }\end{array}$ & $\begin{array}{l}\text { Recognise and manage risk and apply } \\
\text { safe exercise principles and procedures } \\
\text { (e.g. not exercising when unwell or } \\
\text { injured, avoiding prolonged high impact } \\
\text { exercise, administering first aid including } \\
\text { resuscitation techniques, avoiding } \\
\text { excessive exercise). } \\
\text { - Evaluate warm-ups and cool-downs } \\
\text { in terms of safety, effectiveness and } \\
\text { relevance to the specific activity and } \\
\text { take responsibility for their own safe } \\
\text { and effective preparation for and } \\
\text { recovery from activity. }\end{array}$ \\
\hline $\begin{array}{l}\text { Exercise } \\
\text { Effects }\end{array}$ & $\begin{array}{l}\text { Recognise, describe and } \\
\text { feel the effects of } \\
\text { exercise, including } \\
\text { changes to: breathing } \\
\text { (e.g. becomes faster and } \\
\text { deeper), heart rate (e.g. } \\
\text { heart pumps faster), } \\
\text { temperature (e.g. feel } \\
\text { hotter), appearance (e.g. } \\
\text { look hotter), feelings } \\
\text { (e.g. feeling good, more } \\
\text { energetic, tired). }\end{array}$ & $\begin{array}{l}\text { Explain and feel the short- } \\
\text { term effects of exercise (e.g. } \\
\text { breathing increases to } \\
\text { provide more oxygen to the } \\
\text { working muscles, the heart } \\
\text { rate increases to pump more } \\
\text { oxygen to the working } \\
\text { muscles, body temperature } \\
\text { increases because working } \\
\text { muscles produce energy as } \\
\text { heat). }\end{array}$ & $\begin{array}{l}\text { Explain a range of short-term effects } \\
\text { of exercise on the cardiovascular } \\
\text { system (e.g. changes in: breathing and } \\
\text { heart rate, temperature, appearance, } \\
\text { feelings, recovery rate) and musculo- } \\
\text { skeletal system (e.g. increases in } \\
\text { muscular strength and endurance and } \\
\text { flexibility, improved muscle tone and } \\
\text { posture, enhanced functional capacity). } \\
\text { Explain that appropriate training } \\
\text { can improve fitness and } \\
\text { performance and that specific }\end{array}$ & $\begin{array}{l}\text { Explain that training programmes } \\
\text { develop both health-related } \\
\text { components of physical and mental } \\
\text { fitness (e.g. cardiorespiratory fitness, } \\
\text { muscular strength and endurance, } \\
\text { flexibility, body composition) and } \\
\text { skill-related components (e.g. } \\
\text { agility, balance, coordination, } \\
\text { speed). }\end{array}$ \\
\hline
\end{tabular}




\begin{tabular}{|c|c|c|c|c|}
\hline & & & $\begin{array}{l}\text { types of activity affect specific } \\
\text { aspects of fitness (e.g., running } \\
\text { affects cardiorespiratory fitness). }\end{array}$ & \\
\hline $\begin{array}{l}\text { Health } \\
\text { Benefits }\end{array}$ & $\begin{array}{l}\text { Explain that regular } \\
\text { activity improves health } \\
\text { by: helping you feel } \\
\text { good (e.g. happy, } \\
\text { pleased), helping body } \\
\text { parts (e.g. bones, } \\
\text { muscles) to grow, } \\
\text { develop and work well. }\end{array}$ & $\begin{array}{l}\text { - Explain that activity } \\
\text { strengthens bones and } \\
\text { muscles (including the } \\
\text { heart) and helps to keep } \\
\text { joints flexible } \\
\text { - Explain that activity can } \\
\text { help you to feel good about } \\
\text { yourself and can be fun and } \\
\text { social. }\end{array}$ & $\begin{array}{l}\text { Explain a range of long-term benefits } \\
\text { of activity on physical health: reduced } \\
\text { risk of chronic disease (e.g. heart } \\
\text { disease), reduced risk of bone disease } \\
\text { (e.g. osteoporosis), reduced risk of } \\
\text { some health conditions (e.g. obesity, } \\
\text { back pain), improved management of } \\
\text { some health conditions (e.g. asthma, } \\
\text { diabetes, arthritis). } \\
\text { - Explain that activity can enhance } \\
\text { mental health and social and } \\
\text { psychological well-being (e.g. enjoying } \\
\text { being with friends; increased self- } \\
\text { esteem; decreased anxiety) and that an } \\
\text { appropriate balance between work, } \\
\text { leisure and activity promotes good } \\
\text { health. }\end{array}$ & $\begin{array}{l}\text { - Explain that frequent and appropriate } \\
\text { activity enhances the physical, social and } \\
\text { psychological well-being of all } \\
\text { individuals including the young and old, } \\
\text { able-bodied and disabled, and those with } \\
\text { health conditions (e.g. asthma, } \\
\text { depression) and chronic disease (e.g. } \\
\text { arthritis). } \\
\text { - Explain that activity can help to manage } \\
\text { stress and contribute to a happy, healthy } \\
\text { and balanced lifestyle. }\end{array}$ \\
\hline $\begin{array}{l}\text { Activity } \\
\text { Promotion }\end{array}$ & $\begin{array}{l}\text { - Identify when, where and } \\
\text { how they can be active at } \\
\text { school (in and out of } \\
\text { lessons). }\end{array}$ & $\begin{array}{l}\text { - Identify when, where and } \\
\text { how they can be active in } \\
\text { school and outside } \\
\text { - Make decisions about which } \\
\text { physical activities they } \\
\text { enjoy and explain that } \\
\text { individuals have different } \\
\text { feelings about the types and } \\
\text { amounts of activity they do. }\end{array}$ & $\begin{array}{l}\text { - Access information about a range of } \\
\text { activity opportunities at school, home } \\
\text { and in the local community and } \\
\text { identify ways of incorporating activity } \\
\text { into their lifestyles (e.g. walking or } \\
\text { cycling to school, helping around the } \\
\text { home/garden). } \\
\text { - Reflect on their activity strengths and } \\
\text { preferences and know how to get } \\
\text { involved in activities. }\end{array}$ & $\begin{array}{l}\text { Access physical activity personnel (e.g. } \\
\text { coaches, instructors), facilities (e.g. } \\
\text { leisure centres, sport, health/fitness } \\
\text { clubs) and services (e.g. courses, } \\
\text { projects, leaflets) in the local community. } \\
\text { - Explain factors affecting participation } \\
\text { and constraints to being active and } \\
\text { explore how to overcome the latter in } \\
\text { order to access and sustain involvement } \\
\text { in activity. }\end{array}$ \\
\hline
\end{tabular}

Adapted from Harris (2000) psychological well-being of all individuals including the young and old, able-bodied and disabled, and those with health conditions (e.g. asthma, and chronic disease

that activity can enhance

mental health and social and

being with friends; increased self-

esteem; decreased anxiety) and that an appropriate balance between work

Access information about a range of activity opportunities at school, home and in the local community and intify ways of incorporating activity cycling to school, helping around the

Reflect on their activity strengths and involved in activities. eisure centres, sport, health/fitnes clubs) and services (e.g. courses,

- Explain factors affecting participation constraints to being active and order to access and sustain involvement 
